\title{
Review the Effect of Internal Branding on Brand Performance in Shopping Centers in Tehran
}

\author{
Khodayar Palouzian $^{1 *}$ and Mirza Hassan Hosseini ${ }^{2}$ \\ ${ }^{1}$ Faculty teaching member MBA, Marketing Payamenoor University, Iran. \\ ${ }^{2}$ Professor Marketing Payamenoor University, Iran. \\ http://dx.doi.org/10.13005/bbra/2033
}

(Received: 03 February 2016; accepted: 15 March 2016)

\begin{abstract}
Recently branding through various communicative activities, as a means to an organization's success in providing promises of the brand, to respond to expectations set of customers, have been proposed. In an organization, strengthen the brand in the eyes of foreign customers need to strengthen brand position within the organization and among employees. In this study, to evaluate the effect of internal branding in shopping centers in Tehran on employee performance a model with a review of studies that have done in this area were evaluated. Statistical population included employees of shopping centers in Tehran have direct contact with the customer, the number of 323 cases from the statistical population in randomly and clusters method selected and a questionnaire with the whole five-item Likert was distributed. Results showed that all research hypotheses at $5 \%$ error level is significant, and internal branding on employee engagement, a sense of belonging and loyalty of employees to brand has a positive effect.
\end{abstract}

Key words: Internal branding, employee engagement, sense of belonging employees, employees' loyalty, brand performance.

Since the attitude of employees to brand has a significant impact on brand performance is determined by examining study conducted in this regard, that the papers have very little impact on the sense of belonging internal branding, loyalty and commitment of employees to brand at the same time have studied. Recently branding through various communicative activities, as a means to an organization's success in providing promises of the brand, to respond to customers' expectations set of brand, have been proposed ${ }^{1}$. Branding is at two levels internal and external. Foreign branding related to external customers and represents attempt to create an enduring image of the business, among the audience out of the organization. While the internal branding emphasis on improving the perception and behavior of

\footnotetext{
* To whom all correspondence should be addressed. Tel: +989123166435;

E-mail: Palouzian@gmail.com,Palouzian@se.pnu.ac.ir
}

employees as within the organization customers, from the brand of the organization. Hence service branding is more influenced by the activities and behavior of employees of an organization ${ }^{2}$. In an organization, strengthen the brand in the eyes of foreign customers required to strengthen brand position within the organization and in the sight of employees. Cutler says that as long as the brand of organization not is established for the employee and external customers will not be possible to strengthen the brand perspective ${ }^{3}$. Panjaysry and colleagues (2009) found that internal branding coordinates marketing with the management of human resources and significant effect on attitudinal and behavioral aspects as far as the employees at the brand promise ${ }^{4}$. So the attitude of employees to brand has a significant impact on brand performance is determined by examining study conducted in this area very few articles, the impact of internal branding on the sense of belonging commitment and loyalty of employees 
at the same time to the brand have studied and existing studies have examined separately to the parts of it. Panjaysry and colleagues ${ }^{4}$ in 2009 to examine this issue in 4 and 5 stars hotels have addressed. Shopping centers, including organizations that are trying to attract customers and keep existing customers so managers should to pursuing create a better relationship with our customers and meet customer needs, and action to brand promises against customers, and this issue will not be possible unless the betterment of employee attitudes of brand that are associated with customers of shopping centers. By examining that in previous studies, was conducted within the country, a study that to deal the impact of employees attitude to brand performance against address customers was not found For this reason with inspiration from study of Panjaysry and colleagues, aim of this study is to understand the internal branding process from the perspective of employees, that examines the relationship between internal branding and brand's employee performance in relation to providing promise of brand. To achieve the goals of research of the 323 employees in shopping centers that are associated with customers surveys have been conducted.

\section{Theoretical Foundations and issue background}

Internal branding effect on the attitude and behavior of employees some researchers ${ }^{5,6}$. In order to provide customers with brand's promises, to play a central role in branding Services of employees have emphasized. In service marketing triangle by a number of researchers ${ }^{7.9}$ has been promoted also has been emphasized the importance of providing brand promise to customers. Three important elements of include the company, provider and clients.

Their participation in any activity, has committed to provide promises to customers. Providing customer promises, is responsible for brand's employees, which has been provided to determine whether or not the brand promise. To ensure being successful of employees in providing brand's promises to customers, organization is essential to any type of activity including employment, education, motivating, reward and providing equipment and technology to help employees in enhancing their ability to providing promise of the brand to involved ${ }^{10}$. Internal branding to promote brand within the organization, means the same employees, have been mentioned ${ }^{11}$. However, due to the lack of internal branding concepts, there are fewer studies that experimentally internal branding effect on the attitude of the employees (brand identification, brand commitment, brand loyalty) of brand has examined. Bergstrom, Blumenthal and Kradrz in their study concluded that internal branding can be create of brand sense of belonging to the in employees that somehow it is considered indicative oneness of the employees and its cause associated with employees has stated ${ }^{12}$. Panjaysry et al in their study to the effect of internal branding have emphasized on the employees' sense of belonging. Geng and Gris in their study ${ }^{13}$ brand activities of human resources centered and communications that are raised in their paper as a component of dissemination of knowledge; introduce of important levers commitment to the brand. So there is a significant relationship between internal marketing and organizational commitment. Internal marketing can also increase employees' loyalty and in creating commitment of employees also play an important role ${ }^{14}$. Borman et al in their study ${ }^{15}$, to existence of effect of internal communication that is one of the tools of internal branding have noted on commitment of employees to brand. Asnif and Segal ${ }^{16}$ suggest that successful internal branding; create employees' commitment and loyalty. So:

a) H1: internal branding has a positive impact on sense of belonging employees to brand.

b) H2: internal branding has a positive impact on commitment of employees to brand.

c) H3: internal branding has a positive impact on loyalty of employees to brand.

d) H4: internal branding has a positive impact on the performance of employees to brand.

The role of belonging to brand, brand commitment and brand loyalty in the process of internal branding

In studies have been conducted in the field of internal branding ${ }^{17-19}$. To have concluded that internal branding its tools (training and internal communications) leads to increasing the belonging to brand, brand commitment and brand loyalty among employees. It is essential to note that only Panjaysry and Wilson ${ }^{18}$. In their study the distinction between these three attitudes have created while in other studies have not been 
examined these three issues at the same time. For example, some researchers' sense of belonging and loyalty as employee commitment are considered ${ }^{20-}$ ${ }^{22}$ while some researchers are considered them as separate structures ${ }^{23-25}$. A group of researchers ${ }^{26 \text {, }}$ ${ }^{27}$ the theory of Porter et al. ${ }^{22}$ that expresses a sense of belonging, too much effort and tend to staying from the components of the commitment are have criticized. These researchers believe that these components should be considered separately. In the study of miles (1988) that a sense of belonging and commitment has been measured conclude that these two concepts are separate. According to ideas of this research group, feeling a sense of belonging referring to unify with a group, that employees themselves as giving character to that group to know ${ }^{28,29}$. For example, employees who consider they to belong to the organization, its successes and failures know of themselves ${ }^{30}$. Gavtam in his study ${ }^{31}$, classified organization belonging sense to this case: the sense of belonging affiliation and pride of membership of the organization loyalty to the organization and support of organizational goals, perceived homogeneity between the employees and the organization in terms of values and common goals. Panjaysry and colleagues ${ }^{18}$ in defining brand belonging sense have said in such way: employees' belonging sense and perceived high dependence on brand's fate and success. sense of belonging to brand, as an introduction to employee engagement, as the psychological dependence of employees to organization is considered and influenced by the their desire for too much effort in order to achieve brand objectives is defined ${ }^{15}$. So can be said that:

H5: sense of belonging to brand has a positive relationship with employee commitment to the brand.

The term “commitment” widely has been used in the context of internal branding ${ }^{32}$. Brand commitment represents involvement amount and intervention of employees in brand goals and their interest in continuing to work in the organization. Commitment to the brand can be known "the brand's sense of belonging and a sense of his responsibility towards the goals of brand"; also commitment means putting people's willingness to provide energy and his allegiance to the social system is defined ${ }^{33}$. Commitment to the brand, in

Table 1. Cranach's alpha coefficient for the research variables

\begin{tabular}{lccc}
\hline Variable & Number of questions & Cranach alpha coefficient & Source \\
\hline Internal branding & 10 & 75.0 & ] $44_{i} 18[$ \\
sense of belonging to brand & 8 & 71.0 & ] 4 i 29[ \\
commitment to the brand & 3 & 74.0 & ] 4[ \\
Brand loyalty & 5 & 75.0 & ] 4[ \\
Employee Performance & 5 & 82.0 & ] 4[ \\
Total & 31 & 84.0 & \\
\hline
\end{tabular}

Table 2. Demographic profile of participants in the study

\begin{tabular}{llcc}
\hline & & Count & Percentage \\
\hline marital status & Single & 198 & 5.72 \\
& Married & 75 & 5.27 \\
Education & Diploma & 25 & 2.9 \\
& Associate & & \\
& Degree & 69 & 3.25 \\
& BS & 81 & 6.29 \\
& MA & 67 & 5.24 \\
Work experience & 7-1 & 31 & 3.11 \\
(years) & 15-7 & 98 & 3.44 \\
& Above 15 & 54 & 9.35 \\
& & & 8.19 \\
\hline
\end{tabular}

fact is a reflection of the amount of emotional attachment of person to the brand and its identification with its objectives. Components of commitment can be expressed in three cases: Firstly person to accept the values and organization goals, Secondly be willing to do the necessary effort in order to achieve organizational goals and thirdly, an intense desire to be a member of the organization $^{22}$. In fact, commitment to brand is strong desire of organization's employees towards maintain that brand ${ }^{34}$. One of the important elements in the creation of employee relations, employee loyalty, because loyal employees, the main components of a successful business ${ }^{35}$. Most 
studies $^{26,36}$, know the loyalty of employees for the duration of served on the organization. Reichheld also $^{37}$ knows the loyalty tend to stay and cooperation of workers in the present organization. The other hand brand loyalty of employees to respond effectively to customer needs is very important. Pritchard et al. ${ }^{38}$ knows commitment as a tool for employee loyalty. So that:

H6: employee commitment has a positive relationship with the loyalty of employees to the brand.

The purpose of internal branding creating change the behavior of employees to provide the brand promises ${ }^{1,11,39}$. Although the number of researchers support from this theme, but there are less empirical evidence to demonstrate the relationship between internal branding and employee performance of brand in providing brand promises. In general, most of the articles published in the field of internal branding, in internal communications and human resources believe that, when employees are committed to an organization try to provide the brand's promise, they will provide the customers' expectations for brand ${ }^{2}$. However, the assumption that employees' attitudes of brand influenced by their behavior in presenting promises of the brand still is approved so:

H7: the attitude of brand employees' is mediator between internal branding and employee performance of the brand in presenting the brand's promises.

According to literature of the subject in relation to branding and its relationship with the employee's performance with regard to the sense of belonging, commitment and loyalty of employees to brand that was described above, Figure (1) to assess the research hypotheses is presented.

\section{Methodology}

Research plan

The aim of the present study is applied because its result can be helpful in brand

Table 3. Mean, standard deviation and coefficient of correlation between variables

\begin{tabular}{|c|c|c|c|c|c|c|c|}
\hline Variable & mean & SD & $\begin{array}{l}\text { Internal } \\
\text { branding }\end{array}$ & $\begin{array}{l}\text { belonging } \\
\text { to brand }\end{array}$ & $\begin{array}{l}\text { commitment } \\
\text { to brand }\end{array}$ & $\begin{array}{l}\text { Brand } \\
\text { loyalty }\end{array}$ & $\begin{array}{c}\text { Brand } \\
\text { performance }\end{array}$ \\
\hline Internal branding & 25.3 & 68.0 & 1 & - & - & - & - \\
\hline belonging to brand & 62.3 & 65.0 & ${ }^{*} 645.0$ & 1 & - & - & - \\
\hline commitment to the brand & 56.3 & 78.0 & *534.0 & *423.0 & 1 & - & - \\
\hline Brand loyalty & 45.3 & 87.0 & ${ }^{*} 742.0$ & ${ }^{*} 698.0$ & *4340. & 1 & \\
\hline Brand performance & 46.2 & 75.0 & ${ }^{*} 650.0$ & ${ }^{*} 723.0$ & ${ }^{*} 832.0$ & ${ }^{*} 453.0$ & 1 \\
\hline
\end{tabular}

Table 4. Indicators of assessment of the adequacy of the research conceptual model

\begin{tabular}{lccccccccc}
\hline Statistics & ${ }^{2} \chi$ & Df & P-Value & GFI & TLI & CFI & RMSEA & AIC & BIC \\
\hline Amount & 65.734 & 267 & 000.0 & 945.0 & 90.0 & 93.0 & 042.0 & 43.750 & 34.780 \\
\hline
\end{tabular}

Table 5. Path coefficient of the conceptual model

\begin{tabular}{lccc}
\hline Path & Path coefficient & Significance level & Result \\
\hline Internal branding - sense of belonging to brand & 5430. & $05.0 \mathrm{p}<$ & Confirmation \\
Internal Branding - commitment to brand & 367.0 & $05.0 \mathrm{p}<$ & Confirmation \\
Internal branding - brand loyalty & 628.0 & $05.0 \mathrm{p}<$ & Confirmation \\
Internal branding - Employee Performance & 324.0 & $05.0 \mathrm{p}<$ & Confirmation \\
sense of belonging to brand - commitment to brand & 143.0 & $05.0 \mathrm{p}<$ & Confirmation \\
sense of belonging to brand - employees performance & 245.0 & $05.0 \mathrm{p}<$ & Confirmation \\
commitment to brand - loyalty to brand & 178.0 & $05.0 \mathrm{p}<$ & Confirmation \\
commitment to brand - employee Performance & 215.0 & $05.0 \mathrm{p}<$ & Confirmation \\
Brand loyalty - Employee Performance & 345.0 & $05.0 \mathrm{p}<$ & Confirmation \\
\hline
\end{tabular}


management of shopping centers and a strategy to its improved. According to the type of conceptual model and data collection method, this study is descriptive and correlation analysis.

\section{Validity and reliability}

To examine the content validity of the research questionnaire, after translating questions of the questionnaire, several university professors, and experts and managers working in shopping centers, the questionnaires were evaluated and modified so that the questionnaire has satisfactory reliability. Cranach's alpha coefficient was used to evaluate the reliability of the research variables. Since the value of this coefficient is above 0.70 for all variables, so it follows that the questionnaire has appropriate reliability. Table (1) shows Cranach's alpha values for each of the variables. Population and Sample

The study population included all employees of shopping centers in Tehran, who have direct contact with the customer. Cluster sampling was done and the required data were collected. To collect the data, with the whole fiveitem Likert questionnaire from "strongly agree" to "strongly disagree” was used. 323 questionnaires were distributed among the employees and ultimately the number of 273 questionnaires were returned (return rate of $84 \%$ ).

\section{Data analysis}

\section{Analysis of demographic sample}

In this study for273 people completed questionnaires. $65.2 \%$ (178 people) of participants were male and $34.8 \%$ (95 people) were male. The mean age (standard deviation) total number of subjects were 30.18 (3.14) years and for men and women order to 30.37 (3.02) years and 29.91 (3.30) years. Table (2) shows other demographic characteristics of the study population.

According to above table most respondents had Bachelor's degree (29.6 percent) and the majority of employees had work experience less than 7 years old (44.3 percent).

\section{Testing the model and hypotheses}

\section{Correlation between the variables}

Table (3) shows the correlation between variables and mean and standard deviation each of the variables.

According to Table (3) correlation test between variables of research shows that between internal branding and attitude of employees (sense of belonging to brand, brand commitment and brand loyalty) positive correlation is statistically at 5 percent level. Also the same positive correlation between the components of employees attitude to brand with performance of brand, internal branding with brand performance is established, This means that if the internal branding process (training, reward, communication) to be done correctly among the employees of shopping centers can improve employee attitudes to brand as a result of the brand performance will go up. Most of the correlation related to commitment to the brand of employees with brand performance and its lowest for correlation is between variables of sense of belonging to brand and brand commitment.

\section{Hypotheses testing and conceptual model}

To test hypotheses the AMOS software version of 19 was used. Table (4) shows the results of evaluation of the adequacy of the model.

To test the main effects of internal branding for the research variables, structural

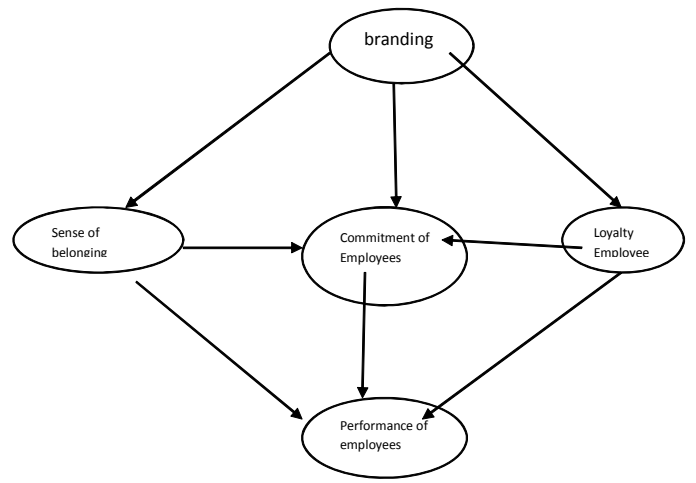

Fig. 1: Research conceptual model

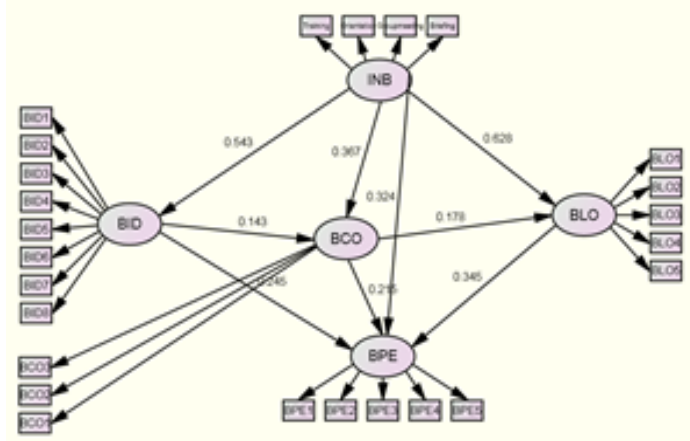

Fig. 2. The standardized path coefficient of model (INTB = internal branding, BID = brand identification, $\mathrm{BCO}=$ brand commitment, $\mathrm{BLO}=$ brand loyalty, BPE = brand performance) 
equation analysis has been used. The goodness of fit statistics, Table 4 shows the appropriateness of the research model for data, ratio of chi-square statistic has a value of 2.75 to the degree of freedom that the critical value of 3 is less and has acceptable amount. Other indicators presented in Table 4 show that the structural model appropriate fitting to the data provide that: So that the amount of GFI, equal to 0.945 and the amount of insole, equal to 0.93 , RMSEA value is equal to 0.042 . According to Table 5 , internal branding and has a significant positive impact on sense of belonging to brand ( $\mathrm{p}<0.05$, 0.54 ), employee commitment ( $\mathrm{p}<0.05,0.36)$ and loyalty of the brand employees $(\mathrm{p}<0.05,0.62)$ which leads to accept the hypotheses of H1, H2, H3. So if necessary training to employees sufficient shopping centers or if employees Justification Meetings held by the managers, will be aware brand's promise better that cause they not valued for brand and commitment and loyalty necessary to the brand establish on their own. According the results, relationship of sense of belonging to brand on Employee Performance ( $<<0.05,0.24)$, employee commitment, to brand on Employee Performance $(p<0.05,0.54)$ and loyalty employees to the brand on employees brand performance ( $\mathrm{p}<0.05,0.34$ ), positively and meaningful have been reported, that hypotheses of H4, H5, H6 and H7 is approved. This means that with sense of belonging and commitment and loyalty in their employees to meet brand promises will be successful.

\section{Conclusion and Suggestion}

Internal branding as a powerful tool and influential on How to brand presenting promises by changing behavior and attitudes of them by employees, have been introduced. This study, the positive impact of internal communications on sense of belonging employees to the brand, employee's commitment to brand and their loyalty to the brand has confirmed.

In particular, was found that the sense of belonging to the brand employees is more influenced by internal branding. also, the results of previous studies that each particular branch of branding effectiveness of internal on the sense of belonging and commitment and loyalty of employees to the brand have studied is confirmed. Also this internal branding study the impact on the behavior of employees in how to brand presenting promises has confirmed. In line with previous studies in various fields (such as marketing and organizational behavior) relationship between the attitudes of employees and internal branding is approved. Allen and Meyer suggest that the positive effect of sense of belonging to brand on employees on the commitment of employees to the brand is as an introduction to their loyalty to brand [40]. This means that if in shopping centers employees by using the educational tools (Justification Meetings, group meetings, training programs, How to communicate effectively with customers) aware of brand promises of the shopping center, creating a sense of belonging in the employees towards the brand. As a result, their employees are committed responsible for presenting promises of brand and this underlying creates loyalty of Employees to the brand of shopping center. When the loyalty and commitment and sense of belonging to the brand among the employees caused be better increasing employee performance to brand so that, those in behaviors and attitudes with customer put in priority the brand interests. such employees are used wholeheartedly their power in order to better presenting brand promises because they know that the success of the brand and the shopping center are known as their success and even to the success of brand and shopping center are acted any works outside the scope of their work. In addition, this study shows that managers can expect be further the employee commitment, with increasing their sense of belonging to brand. Similarly with increasing commitment of employees to ensure that their loyalty to brand is strong. All this positive attitudes can be seen in the success of internal branding in brand of shopping center. Sense of belonging and loyalty has mediating effect on the relationship between branding and performance of the employees. It encourages managers to attitude of employees as an effective factor in their performance, to be considered by internal branding. When the internal branding, sense of belonging and commitment to the branding employees that are affected, Brand performance can be better than when the internal branding do not has an effect on the motivation of employees. However, managers can by using the branding caused be changed the behavior of employees, in order to presenting brand promises by them. 


\section{REFERENCES}

1. Drake S, Gulman M, Roberts S. Light their fire: using internal marketing to ignite employee performance and wow your customers: Kaplan Publishing; 2005.

2. De Chernatony L, Riley FDO. The chasm between managers' and consumers' views of brands: the experts' perspectives. Journal of Strategic Marketing 1997; 5: 89-104.

3. Kotler P. Marketing Management 11th Edition, p472. Prentice-Hall Publishers-Pearson Upper Saddle River, New Jersey; 2003.

4. Wirtz J, Johnston R, Sin Seow K, Punjaisri K, Wilson A, Evanschitzky H. Internal branding to influence employees' brand promise delivery: a case study in Thailand. Journal of Service Management 2009; 20: 561-79.

5. Olins W, Council D. The new guide to identity: Gower Aldershot; 1995.

6. O’Loughlin D, Szmigin I, Turnbull P. Branding and relationships: Customer and supplier perspectives. Journal of financial services marketing 2004; 8: 218-30.

7. Bitner MJ. Building service relationships: it's all about promises. Journal of the Academy of marketing science 1995; 23: 246-51.

8 .Grönroos C. Service management and marketing: managing the moments of truth in service competition: Jossey-Bass; 1990.

9. Philip K. Marketing management: analysis planning implementation and control. PrenticeHall of India; 1994.

10. Zeithaml VA, Bitner MJ, and Gremler DD. Services marketing: Integrating customer focus across the firm. 2006.

11. Ahmed PK, Rafiq M, Saad NM. Internal marketing and the mediating role of organisational competencies. European Journal of Marketing 2003; 37: 1221-41.

12. Bergstrom A, Blumenthal D, Crothers S. Why internal branding matters: The case of Saab. Corporate Reputation Review 2002; 5: 133-42.

13. King C, Grace D. Building and measuring employee-based brand equity. European Journal of Marketing 2010; 44: 938-71.

14. Boyd G, Sutherland M. Obtaining employee commitment to living the brand of the organisation. African Journal of Business Management 2006; 37.

15. Burmann C, Zeplin S. Building brand commitment: A behavioural approach to internal brand management. The Journal of Brand Management 2005; 12: 279-300.

16. Asif S, Sargeant A. Modelling internal communications in the financial services sector.
European Journal of Marketing 2000; 34: 299318.

17. Papasolomou I, Vrontis D. Building corporate branding through internal marketing: the case of the UK retail bank industry. Journal of product \& brand management 2006; 15: 37-47.

18. Punjaisri K, Wilson A. The role of internal branding in the delivery of employee brand promise. Journal of Brand Management 2007; 15: $57-70$.

19. Papasolomou I, Vrontis D. Using internal marketing to ignite the corporate brand: The case of the UK retail bank industry. Journal of Brand Management 2006; 14: 177-95.

20. Legge K. Human Resource Management: Rhetorics and Realities: Anniversary Edition: Palgrave Macmillan; 2005.

21. Mowday RT, Porter LW, Steers RM. Employeeorganization linkages: The psychology of commitment, absenteeism, and turnover: Academic Press; 2013.

22. Porter LW, Steers RM, Mowday RT, Boulian PV. Organizational commitment, job satisfaction, and turnover among psychiatric technicians. Journal of applied psychology 1974; 59: 603.

23. Loveman GW. Employee satisfaction, customer loyalty, and financial performance an empirical examination of the service profit chain in retail banking. Journal of Service Research 1998; 1: 18-31.

24. Ashforth BE, Mael F. Social identity theory and the organization. Academy of management review 1989; 14: 20-39.

25. Silvestro R. Dispelling the modern myth: Employee satisfaction and loyalty drive service profitability. International Journal of Operations \& Production Management 2002; 22: 30-49.

26. Benkhoff B. Disentangling organizational commitment: The dangers of the OCQ for research and policy. Personnel Review 1997; 26: 114-31.

27. Peccei R, Guest D. The Dimensionality and Stability of Organizational Commitment: A Longitudinal Examination of Cook and Wall's (1980) Organizational Commitment Scale (BOCS): London School of Economics and Political Science, Centre for Economic Performance; 1993.

28. Tolman EC. Identification and the postwar world. The journal of abnormal and social psychology 1943; 38: 141.

29. Mael F, Ashforth IS. Alumni and their alma mater: A partial test of the reformulated model of organizational identification. Journal of organizational Behavior 1992; 13: 103-23.

30. James LR, Hartman A, Stebbins MW, Jones AP. 
relationships between psychological climate and a vie model for work motivation1. Personnel Psychology 1977; 30: 229-54.

31. Gautam T, Van Dick R, Wagner U. Organizational identification and organizational commitment: Distinct aspects of two related concepts. Asian Journal of Social Psychology 2004; 7: 301-15.

32. Ind N. Living the brand: London; 2001.

33. Ng TW, Feldman DC. Affective organizational commitment and citizenship behavior: Linear and non-linear moderating effects of organizational tenure. Journal of Vocational Behavior 2011; 79: 528-37.

34. Baron S, Patterson A, Oakes S, Harris K, Punjaisri K, Evanschitzky H, Wilson A. Internal branding: An enabler of employees' brandsupporting behaviours. Journal of Service Management 2009; 20: 209-26.

35. Larsen L. Employee loyalty survey. Journal of
People Dynamics 2003: 10-2.

36. Bloemer J, Odekerken-Schröder G. The role of employee relationship proneness in creating employee loyalty. International Journal of Bank Marketing 2006; 24: 252-64.

37. Reinchheld FF. The loyalty effect: The hidden force behind growth, profits, and lasting value. Long Range Planning 1996; 6: 909.

38. Pritchard MP, Havitz ME, Howard DR. Analyzing the commitment-loyalty link in service contexts. Journal of the Academy of Marketing Science 1999; 27: 333-48.

39. BOOne M. The importance of internal branding. Sales and Marketing Management 2000; 9: 368.

40. Allen NJ, Meyer JP. The measurement and antecedents of affective, continuance and normative commitment to the organization. Journal of occupational psychology 1990; 63: 118. 